\title{
MURABAHAH TRANSACTION IN SHARIA BANK WITH WORK POTENTIALLY INFRINGE THE SYARIAH ECONOMIC LAW
}

\author{
Minanul Aziz \\ Student in Program Doktor IImu Hukum Unissula \\ E-mail :minannajah@yahoo.com
}

\begin{abstract}
Islamic bank generally deputes customers to buy product for supplier in terms of deferred payment sale purchase agreement, there are possibilities: an agreement upon the delivery of money, and customers are not in accordance with bank in spending money. The agreement of deferred payment sale is appropriate with the advisory opinion of National Sharia Board, goods officially become the property of bank. The customers are generally not in accordance with bank in spending money, so that the value are often not in accordance with the price of bank within the agreement, it can be concluded based on advisory opinion of National Sharia Board that deferred payment sale is invalid.
\end{abstract}

Keywords : Transaction, Deferred payment sale, Deputyship, Sharia

\section{A. INTRODUCTION}

One of the most popular figh schemes used by sharia banking is the scheme of buying and selling murabaha. Murabahah is the most widely used financing product by sharia banking in business activities. Today, murabaha accounts for $66 \%$ of all investment transactions of Islamic banks in the world, even in Indonesia according to Sutan Remy Sjahdeini estimated more than $80 \%$ of investment and financing products from sharia banks and sharia business units in Indonesia in the form of murabahah transactions. ${ }^{1}$ Murabahah is the buying and selling of goods at the original price with an additional profit agreed. Since the definition is called "agreed advantage", the murabaha characteristic is that the seller must notify the buyer of the purchase price of the goods and state the amount of profit added to the cost. ${ }^{2}$ Mechanism of murabahah sale transaction between bank and customer is as follows: $a$. The Customer comes to the Sharia Bank to submit an application to purchase an item by meeting all requirements; $b$. The Customer promises to buy the goods ordered; c. Sharia Bank purchases goods ordered to the supplier; $d$. Sharia banks and customers are engaged in buying and selling murabahah; e. The sharia bank represents the

\footnotetext{
Sutan Remy Sjahdeini, Perbankan Syariah, Produkproduk dan Aspek-aspek Hukumnya, Kencana, Jakarta, 2014, page. 190-191.

2 Sutan Remy Sjahdeini, op.cit., page. 113.
}

supplier to deliver the goods to the customer; $f$. Goods supplied by suppliers to customers; $g$. The customer pays the installment to the sharia bank in accordance with the agreement. Murabaha transaction mechanism as above, is a provision of genuine murabaha transactions, ie the bank does not represent to customers to buy goods to third parties, but the bank directly buy goods to the supplier, then sell it to the customer.

But in general Islamic banks in Indonesia do not bother to buy goods that will be sold to customers, but Islamic banks represent customers to buy goods to be bought themselves, so the mechanism becomes as follows: a. The Customer comes to the Sharia Bank to apply for the purchase of an item by meeting all requirements; $b$. The Customer promises to buy the goods ordered; c. Bank Syariah represents to the customer to buy the intended goods to the supplier; $d$. Implementation of customer agreement as the representative of sharia bank with supplier; e. Sharia banks and customers are engaged in buying and selling murabahah; $f$. The sharia bank represents to the supplier to deliver the goods to the customer; g. Goods supplied by suppliers to customers; $h$. The customer pays the installment to the sharia bank in accordance with the agreement.

The sale of murabahah must be in accordance with the DSN-MUI fatwa concerning murabahah, 
and if the sharia bank represents to the customer to buy the goods to a third party, then in addition must be in accordance with the DSN-MUI fatwa on murabahah, also must be in accordance with the fatwa DSN- MUI about Wakalah.

Although normatively the issue of murabahah sale agreement with wakalah has been regulated in the DSN-MUI fatwa, but the practice is still loaded with alleged sharia violations committed by some employees of sharia banks, especially sharia violations committed by customers when the bank representative to buy goods from third party. This is because there is a possibility of sharia bank employees there is a lack of understanding of sharia economic law. Although every syariah bank has a Sharia Supervisory Board, but in reality, the Sharia Supervisory Board only exists in the Head Office, so it can not directly supervise bank operations every day.

At the time when sharia bank is not ready to buy goods to be sold to customers, then the bank asks customers to buy goods to third parties, by giving a sum of money, then there is alleged execution akad buying and selling murabaha done at the time of handover money, at that time, the merchandise did not exist, or even the possibility, after the customer received the money, he went and returned only when willing to pay the installments. If so, then it is contrary to the fatwa of DSN-MUI which states: If the bank wants to represent to customers to buy goods from third parties, the sale and purchase agreement of murabahah must be done after the goods, in principle, become the property of the bank. ${ }^{3}$ So if the bank represents to the customer to buy the goods to a third party, and the contract of sale of murabahah done at the time of delivery of money, then the contract is not valid. In general, customers do not understand sharia law law, in addition they generally do not care about the existing contract, which is important for them to get the money, then he does not understand how to be a representative, there is the possibility he violated the law of Shari'a, carry out his duties as a representative, or intentionally betray the mandate, whereas one of the requirements of

3 DSN-MUI, Himpunan Fatwa Keuangan Syariah, Erlangga, Jakarta, 2014, hlm. 64. a representative must also be trustworthy, if the client is not trustworthy, then the authorization or wakalah to the customer is also illegitimate, if at the time of initial purchase alone is not valid, then Furthermore, the contract of sale and purchase of murabahah is also not valid. This condition of course will harm one of the parties who transact and have a negative impact on Islamic banks and customers themselves. So when will the sale of murabaha deal, whether at the time of delivery of money, or after the goods have been officially owned by the bank. And is the customer who is a bank representative trustful and has spent money in accordance with the will of the bank.

\section{B. DISCUSSION}

The sources of law that can be used as the juridical foundation of sharia banking in Indonesia can be classified on two aspects, namely, normative law and positive law. ${ }^{4}$ Normative law means the legal basis derived from Islamic norms : ${ }^{5}$

1. Al-Qur'an and Hadith;

2. Fatwa of the National Sharia Council Mejelis Ulama Indonesia (DSN-MUI); Article 1 Sub-Article 12 of the Law of the Republic of Indonesia Number 21 Year 2008 Concerning Sharia Banking states:

The principle of sharia is the principle of Islamic law in banking activities based on fatwas issued by institutions that have authority in the determination of fatwa in the field of sharia. Abdul Ghofur Anshori said: ${ }^{6}$ nstitutions that have authority in the determination of fatwa in the field of sharia is the National Sharia Council-Majelis Ulama Indonesia (DSN-MUI). The Fatwa of the National Sharia Council of the Indonesian Council of Ulema related to this research are:

a. Fatwa DSN-MUI No. 04 / DSN-MUI / IV / 2000 concerning Murabahah;

b. Fatwa DSN-MUI No. 10 / DSN-MUI / IV / 2000 on Wakalah.

\footnotetext{
4 Ahmad Dahlan, Bank Syariah, Teoritik, Praktik, Kritik, Teras, Yogyakarta, 2012, page. 85.

5 Ibid., page 85.

6 Abdul Ghofur Anshori, Hukum Perbankan Syariah (UU No. 21 Tahun 2008), Refika Aditama, Bandung, 2013, page. 5 .
} 
3. Compilation of Sharia Economic Law (KHES).

What is meant by positive law is the prevailing laws and regulations of the country, namely: ${ }^{7}$

1. The Constitution of the Unitary State of the Republic of Indonesia;

Dedi Ismatullah said that implementing sharia economy is a form of implementation of Article 29 paragraph (2), then the state has the obligation to protect the legal rights for every citizen. ${ }^{8}$

2. Civil Code;

3. Law no. 7 of 1992 concerning Banking, as has been amended by Law no. 10 of 1998;

Article 6 Sub-Article $\mathrm{m}$ of Law no. 10 of 1998, stipulates that: "Commercial Bank provides financing and / or conducting other activities based on sharia principles, in accordance with provisions stipulated by Bank Indonesia". Article 13 letter c of Law no. 10 of 1998 , stipulates that: "Rural Bank provides financing and fund placement based on sharia principles, in accordance with provisions stipulated by Bank Indonesia". Article 1 number 3 of Law no. 10 of 1998, stipulates that: "Commercial Bank is a bank conducting business activities conventionally and / or based on sharia principles which in its activities provide services in the traffic mpembayaran. Article 1 Sub-Article 4 of Law no. 10 of 1998, stipulates that: "Rural Bank is a bank conducting business in a conventional and / or based on sharia principles which in its activities do not provide services in the payment traffic". 9

4. Law no. 40 Year 2007 regarding Limited Liability Company;

5. Law no. 21 of 2008 concerning Sharia Banking;

6. Regulation of Bank Indonesia no. 6/24 / PBI / 2004 concerning Commercial Bank conducting business activities based on

\footnotetext{
Sutan Remy Sjahdaeni, Perbankan Syariah, Produkproduk dan Aspek-aspek Hukumnya, Kencana, Jakarta, 2014, page. 1

8 http://www.mahkamahkonstitusi,go.id

9 Rachmadi Usman, Aspek Hukum Perbankan Syariah di Indonesia, Sinar Grafika, Jakarta, 2012, page. 82.
}

sharia principles as amended by Bank Indonesia Regulation no. 7/35 / PBI / 2005;

7. Bank Indonesia Regulation no. 6/17 / PBI / 2004 concerning Rural Banks Based on Sharia Principles as amended by Bank Indonesia Regulation no. 8/25 / PBI / 2006;

8. Bank Indonesia Regulation no. 8/3 / PBI / 2006 concerning Amendment of Conventional Commercial Banks into Commercial Banks conducting business activities based on sharia principles and the opening of a bank office conducting business based on sharia principles by conventional commercial banks, as amended by Bank Indonesia Regulation no. 9/7 / PBI / 2007;10

9. Regulation of the Financial Services Authority. ${ }^{11}$

Article 1 point 11 of the Financial Services Authority Regulation No. 31 / POJK.25 / 2014 on the Implementation of Sharia Financing Business states: "Murabahah is the sale and purchase of an item by confirming its purchase price (purchase price) to the buyer and the buyer pays it at a margin value as profit according to the agreement of the parties". ${ }^{12}$

Table 1

\section{Frequency of Murabahah Agreement In Sragen BPRS on 2015}

\begin{tabular}{|c|ccc|}
\hline No. & $\begin{array}{c}\text { Implementation } \\
\text { of the contract }\end{array}$ & Frequency & $\begin{array}{c}\text { Percentage } \\
\text { (\%) }\end{array}$ \\
1 & Before any goods & 1 & $10 \%$ \\
2 & Before any goods & 9 & $90 \%$ \\
& Amount & 10 & $100 \%$ \\
\hline
\end{tabular}

Sumber: Analysis Sekundary Data, 2015

10 Ibid., page. 83-84.

11 The Financial Services Authority (OJK) is a state institution established under Law Number 21 Year 2011 which functions to organize an integrated regulatory and supervisory system on the overall activities within the financial sector. OJK was established to replace the role of Bank Indonesia in regulating and supervising banks, as well as to protect consumers of the financial services industry. http://id.wikipedia.org/wiki.

12 Materi ljtima' Sanawi (Annual Meeting) Dewan Pengawas Syariah X Tahun 2014, page 172. 
Based on Table 1 it can be seen that from 10 secondary data (documents) that exist in SRB Sragen that most of the contract or sale transaction of murabahah executed after the goods in principle become the property of the bank or goods already exist, that is 9 documents $(90 \%)$, while a small part of the contract or sale transaction of murabahah is executed before the goods in principle become the property of the bank, which is 1 document (10\%).

Table 2

Frequency of Customer Attitude When Becoming a Bank Representative at BPRS Sragen Tahun 2015

\begin{tabular}{|c|lcc|}
\hline No. & Attitude & Frequency & $\begin{array}{c}\text { Persentage } \\
(\%)\end{array}$ \\
\hline 1 & can be trusted & 2 & $20 \%$ \\
2 & Can't be trusted & 8 & $80 \%$ \\
& Amount & 10 & $100 \%$ \\
\hline
\end{tabular}

Sumber : Analys Primary Data, 2015

Based on Table 2 of 10 respondents, there are majority of customers who have unsafe attitude when they become bank representative to buy goods to be purchased, that is as many as 8 people $(80 \%)$, while the minority of customers who have the attitude of trust is only 2 people $(20 \%)$.

From Table 1, the results show that from 10 secondary data (documents) in SRB Sragen that most of the contract or sale transaction of murabahah is done after the goods in principle become the property of the bank or the goods already exist, that is 9 data / documents (90 \%) and supported with primary data. Murabahah including buying and selling, therefore, murabaha must meet the requirements as a condition of buying and selling. In the Compilation of Islamic Economic Law Article 76 point a mentioned: "Goods are sold must already exist". Fatwa Dewan Syariah Nasional No. 04 / DSN-MUI / IV / 2000 in the General Provision concerning murabahah number 9 states: "If the bank wishes to represent customers to purchase goods from third parties, the sale of murabahah must be done after the goods, in principle, belong to the bank".
According to Bagya Agung Prabowo ${ }^{13}$ that in Islamic teachings for the legality of a contract must be fulfilled and the terms of a contract. Rukun akad is an absolute element that must exist and is the essence in every contract. If one of the pillars does not exist, the shari'a contract is never seen. While the requirement is a trait that must exist in every rukun, but not the essence of the contract.

This quote is in accordance with the results of research that the authors do in Sharia Rural Bank (BPRS) Sragen. From the results obtained that murabahah transaction in the bank most have been done after the goods that became the object of buying and selling has been there.

From Table 2, the results of the study show that from 10 respondents, the attitude of the customer or former customer of Sharia Rural Banks (BPRS) Sragen who became the bank representative to buy goods to third party when filing murabahah financing, most have unsafe attitude, as many as 8 people ( $80 \%$ ). Unauthorized representatives, resulting in the illegality of wakalah law. In Fatwa Dewan Syariah Nasional (DSN-MUI) no. 10 / DSN-MUI / IV / 2000 on Wakalah, mentioned: b. Terms of the representative (representing): 1) Legal competence; 2) Can perform the tasks represented to him; and 3) Representatives shall be assigned persons.

In the Compilation of Sharia Law Article 471 states: 1) If the power of attorney violates the contract, then the authorizer shall have the right to refuse or accept the act; 2) Although the goods purchased as mentioned in paragraph (1) benefit the authorizer, the proxy is considered to have bought the goods for himself. If the assignee has violated the contract, and has been deemed to have purchased the goods for himself, then the murabahah contract is not valid, since the proxy has purchased his own goods.

Customers who become bank representatives to buy goods to third parties are mostly not trustworthy. The case is that most customers do not spend all the money given by the bank to customers, but customers embezzle some money and tell the bank that the money is all gone. So the bank considers the price of goods

${ }_{13}$ Bagya Agung Prabowo, Aspek Hukum Pembiayaan Murabahah Pada Perbankan Syariah, UII Press, Yogyakarta, 2012, page 55. 
purchased is worth the money that has been given to the customer, in fact, the price of goods is not as much money received from the bank. In the end, when a contract occurs, the original initial purchase price is unknown to the bank.

In the Compilation of Islamic Economic Law Article 116 number (3) is mentioned: The seller must honestly tell about the cost of goods to the buyer and the cost required. Fatwa Dewan Syariah Nasional No. 04 / DSN-MUI / IV / 2000 in the general provisions regarding murabahah number 6 states: "The bank then sells the goods to the customer (buyer) at the selling price of the purchase price plus the profit margin". In this connection, the bank must honestly notify the cost of goods to the customer and the necessary costs.

\section{CONCLUSION}

From discussion in above, can be concluse that: The murabahah sale transaction agreement in Sharia Rural Bank (BPRS) of Sragen has been largely correct in accordance with sharia economic law. Customers who become vice banks to buy goods to third parties, the majority is not mandatory, so the potential to violate sharia economic law.

Shariah banks, you should avoid murabahah sale transaction with wakalah. To the National Sharia Council, it is advisable to eliminate or remove the General Provision of Murabaha in Islamic Banks number 9 which has the potential to violate sharia economic law.

\section{BIBLIOGRAPHY}

Abdul Ghofur Anshori. 2013. Hukum Perbankan Syariah (UU No. 21 Tahun 2008), Refika Aditama, Bandung.

Adiwarman A. Karim. 2013 Bank Islam, Analisis Fiqih dan Keuangan, Raja Grafindo Persada, Jakarta.

Ahmad Dahlan. 2012. Bank Syariah, Teoritik, Praktik, Kritik, Teras, Yogyakarta.

Bagya Agung Prabowo. 2012. Aspek Hukum Pembiayaan Murabahah Pada Perbankan Syariah, UII Press, Yogyakarta.

DSN-MUI. 2014. Himpunan Fatwa Keuangan Syariah, Erlangga, Jakarta.

Lexy J. Moeloeng. 2007. Metode Penelitian Kualkitatif, Remaja Rosda-karya, Bandung.

Materi ljtima' Sanawi (Annual Meeting) Dewan Pengawas Syariah X Tahun 2014.

Muhammad Syafi'i Antonio. 2014. Bank Syariah Dari Teori ke Praktik, Gema Insani, Jakarta.

Mukhtar. 2013. Metode Praktis Penelitian Deskriptif Kualitatif, Referensi, Jakarta.

Rachmadi Usman. 2012. Aspek Hukum Perbankan Syariah di Indonesia, Sinar Grafika, Jakarta.

Sabian Utsman. 2014. Metodologi Penelitian Hukum Progresif, Pustaka Pelajar, Yogyakarta.

Soerjono Soekanto. 2014. Pengantar Penelitian Hukum, UI Press, Jakarta.

Soetandyo Wignyosoebroti. 2002. Hukum, Paradigma, Metode dan Dina-mika Masalahnya, Elsam dan Huma, Jakarta.

Sudarwan Danim. 2002. Menjadi Peneliti Kualitatif, Pustaka Setia, Bandung.

Sutan Remy Sjahdeini. 2014. Perbankan Syariah, Produk-produk dan Aspek-aspek Hukumnya, Kencana, Jakarta.

Zainuddin Ali, Metode Penelitian Hukum, Sinar Grafika, Jakarta, 2013. 
The Constitution of the Unitary State of the Republic of Indonesia.

Code of Civil law.

Law no. 7 of 1992 concerning Banking, as amended by Act no. 10 Year 1998.

Law no. 40 Year 2007 regarding Limited Liability Company.

Law no. 21 of 2008 concerning Sharia Banking.

Bank Indonesia Regulation no. 7/35 / PBI / 2005.

Bank Indonesia Regulation no. 8/25 / PBI / 2006.

Bank Indonesia Regulation no. 9/7 / PBI / 2007.

Regulation of the Financial Services Authority No. 31 / POJK.25 / 2014

Regulation of the Supreme Court of the Republic of Indonesia Number 02 Year 2008 concerning Compilation of Sharia Economic Law.

Fatwa DSN-MUI No. 04 / DSN-MUI / IV / 2000 concerning Murabahah.

Fatwa DSN-MUI No. 10 / DSN-MUI / IV / 2000 on Wakalah.

http://www.mahkamahkonstitusi,go.id

http://id.wikipedia.org/wiki. 